Asian J Agric \& Biol. 2022(3).

$\mathrm{AJAB}$

DOI: $10.35495 /$ ajab.2020.08.452

Original Article

\title{
Response of groundnut to lime sources on acid sandy loam
}

\author{
Nwite James Nte ${ }^{1}$, Igwe Thomas Sunday ${ }^{1}$, Akande Oluyemi Solomon ${ }^{2}$, Enyioko Chimezie Onyeogoziri ${ }^{2}$, \\ Nwibo Simon Uguru3 ${ }^{3}$, Mbam Boniface Nwangele ${ }^{3}$, Orji Jephter Ebuka ${ }^{4}$ \\ ${ }^{1}$ Department of Soil Science and Environmental Management, Faculty of Agriculture and Natural Resources Management, \\ Ebonyi State University, Abakaliki, Nigeria \\ ${ }^{2}$ Federal College of land Resources Technology, Owerri, Nigeria \\ ${ }^{3}$ Department of Agricultural Economics, Extension and Management, Faculty of Agriculture and Natural Resources \\ Management, Ebonyi State University, Abakaliki, Nigeria \\ ${ }^{4}$ Department of Agriculture, Alex Ekwueme Federal University, Ikwo, Ebonyi State, Nigeria
}

\section{Received:}

September 30, 2020

Accepted:

June 10, 2021

Online First:

November 03, 2021

Published:

June 06, 2022

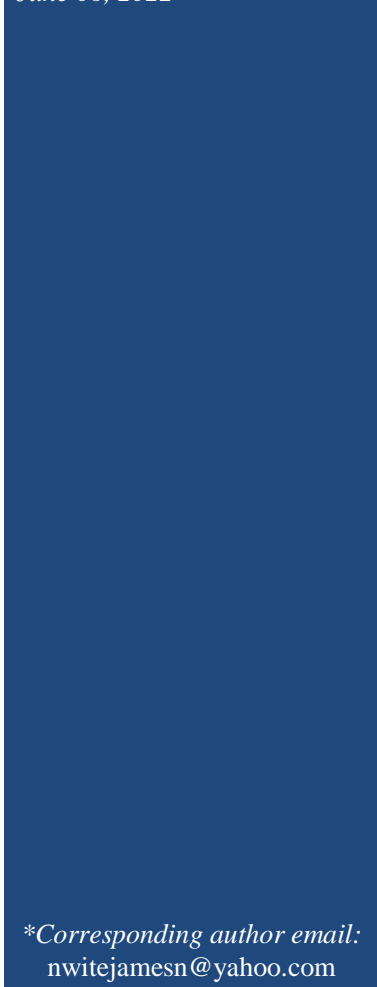

\section{Abstract}

Soil acidity causes a lot of productivity losses annually. The possibility of determining response of groundnut to lime-treated acid sandy loam was studied. The treatments comprise control (0) and $0.2 \mathrm{tha}^{-1}$ or $0.32 \mathrm{~kg} \mathrm{plot}^{-1}$ each of limes in research farm at Ebonyi State University, Nigeria. Field was laid out in randomized completely block design (RCBD) with five replications and plot dimensions of $4 x 4 \mathrm{~m}$. All treatments received uniform agricultural practices. Data were analyzed using statistical analysis system. Results indicate significant $(\mathrm{P}<0.05)$ reductions of bulk densities by woodash at $13 \%$ each and increased hydraulic conductivities by 35 and $61 \%$ compared to control for the two seasons. Calcium Oxide recorded 11 and 14\% significant increase of $\mathrm{MWD}$ as $\mathrm{CaCo}_{3}$ and woodash improved $\mathrm{pH}$ at significant levels of 18 and $14 \%$ for the same seasons. Total $\mathrm{N}$ significantly increased at 13 and $7 \%$ each for $\mathrm{CaCo}_{3}$ and $\mathrm{CaO}$ for the seasons. Maximum significant levels of 32 and $30 \%$ for $\mathrm{Ca}, 15$ and $23 \%$ for $\mathrm{Na}$ and $29 \%$ each for BS were obtained for woodash for the same seasons. Calcium Carbonate induced maximum germination counts of 100 and $99 \%<5 \mathrm{DAP}$ and significant plant heights of 10 and 7\%, pod yields of 57 and $55 \%$ as well as seed yields of 30 and $26 \%$ for two the seasons. Production losses of 89 and $76 \%$ in groundnut were recorded within the two seasons due to nonamendment. The present investigation suggests that soil physical and chemical properties as well as groundnut yield can be maximally improved by $\mathrm{CaCo}_{3}$ or wood ash at $0.2 \mathrm{tha}^{-1}$ or $0.32 \mathrm{~kg} \mathrm{plot}^{-1}$ and minimally by $\mathrm{CaO}$.

Keywords: Acid, Groundnut, Lime, Response, Sandy loam

\section{How to cite this:}

Nte NJ, Sunday IT, Solomon AO, Onyeogoziri EC, Uguru NS, Nwangele MB and Ebuka OJ, 2022. Response of groundnut to lime sources on acid sandy loam. Asian J. Agric. Biol. 2022(3). DOI: https://doi.org/10.35495/ajab.2020.08.452 


\section{Introduction}

Groundnut (Arachis hypogea L.) is a leguminous crop which belongs to the family Leguminosae. It is well adapted to semi-arid and subtropical regions of the world but extensively cultivated in sub-Saharan Africa with Nigeria being the largest producer in West Africa (Ajeigbe et al., 2016). Ajeigbe et al. further notes that Nigeria's production accounts for more than $51 \%$ of the entire sub-region and $10 \%$ global outputs respectively. Groundnut is eaten both by human and animals in different forms. It is a good source of dietary food components such as protein (25-34\%), oil and fat (48-50\%), and vitamins (Ranga et al., 2010). There is ready market for the crop which starts from farm gate. Bulk purchases can be made in markets and employs over $30 \%$ of local teeming population who engage in the production value chain (NPAFS, 2010).

The crop can thrive on all types of soils but preferably on well drained sandy loam, light coloured soil and silty loam (Lourduraji, 1999), but optimal economic yields are obtained in rich sandy loams (Mukhtar et al., 2014), because of its ability to ease off seed penetration and harvests. Poor and marginal yields are common in heavy hydromorphic soils especially as they cause water logging and detachment of seeds during harvest. Soils with optimum temperature range $\left(20-30^{\circ} \mathrm{C}\right)$, adequate moisture regime and of high to medium fertility status especially with adequate concentrations of $\mathrm{P}$, $\mathrm{S}, \mathrm{Ca}, \mathrm{Mg}, \mathrm{K}$ in addition to containing micronutrients such as $\mathrm{Cu}, \mathrm{Zn}$ and $\mathrm{Fe}$ give encouraging yields (Angin and Yaganoglu, 2011). Nevertheless, the crop can be grown under low fertility condition with good management practices. In addition, rainfall between $250-1500 \mathrm{~mm}$, which is well spread during the period of growth with sufficient sunlight are ideal for high yield. The crop can perform well under $\mathrm{pH}$ regime of 6.0-6.5 and slightly alkaline soil between 8.0-8.5 but strongly acidic $(<\mathrm{pH} 5.0)$ or alkaline $(>\mathrm{pH} 9.0)$ condition limits yield optimization. It can be grown under mixed cropping culture often with maize because of its low demand for nutrients most especially $\mathrm{N}$ unlike other crops (Ajeigbe et al., 2016). Highest yield is possible with rotational cropping system but continuous cultivation coupled with low addition of inputs such as lime or organic and inorganic amendments hamper nutrients release and aggravate yield reduction of the crop (Ajeigbe et al., 2016). Limes are chemical elements of either monovalent $(\mathrm{CaO}$ or $\mathrm{MgO})$ or trivalent $\left(\mathrm{CaCo}_{3}\right)$ in form or other materials such as wood ash or charcoal used for the main purpose of soil treatment to reduce acidity (Sobulo, 2000), and improve its general condition. Amendment of lime on soil has been noted to improve soil structure, porosity, aggregation, bulk density and water transmissivity (Cahn et al., 2017). According to Erkki and Hedlund (2016), lime stabilizes organic matter content through enhanced nutrients mineralization. Among the nutrients stimulated and made available in the soil include: $\mathrm{N}$, $\mathrm{P}, \mathrm{K}, \mathrm{Ca}$ and $\mathrm{Mg}$. Additionally, $\mathrm{Al}$ and $\mathrm{Mn}$ solubility or their toxicities in soil including $\mathrm{Al}^{+}$and $\mathrm{H}^{+}$ exchange are reduced (Adeli et al., 2017) and this boosts CEC activity. Nitrogen fixation is promoted through liming with reduction of biological oxygen demand (BOD) and biochemical oxygen demand (COD) (Adeli et al., 2017). These condition the soil for beneficial micro organisms to function at optimal capacity for the benefit of the crop.

In Nigeria, soil acidity is a major limitation to economical yield of legumes due to poor root proliferation, which affects nutrition. For instance, $75 \%$ out of total land area $>500 \mathrm{~m} \mathrm{ha}^{-1}$ put under arable crop production for which $<100$ million ha used for groundnut production is subjected to between very strongly ( $\mathrm{pH} 5.0$ ) to extremely (> pH 4.5) acidic condition (Ohiri and Ano,1988; FDALR,1985; Nweke and Nsoanya, 2013) or alkalinity ( $>\mathrm{pH} 8.5$ ), accounting for $>65 \%$ of annual losses in the crop production and $>35 \%$ of total reduction in productivity for the crop (Ntare et al., 2008). At Abakaliki, > $5.5 \mathrm{~m}$ ha of arable lands and legumes cultivated areas are put at fertility marginal condition leading to $>45 \%$ reduction in groundnut yield (Anikwe et al., 2005). Soil acidity is inhibitive to nutrients precipitation and suppressive to crop growth and yield. In support of this, Mulungu et al. (2013) noted that in acidic soil, Ca or Mg availability is hindered in addition to beneficial nutrients such as $\mathrm{N}, \mathrm{P}$ and $\mathrm{S}$, which are important to groundnut production. Contributing, Donovan et al. (2002) reported that groundnut plants are sensitive to extreme salinity and acidity. Low $\mathrm{pH}$ decreases lateral branches, and causes chlorosis leading to stunted growth, poor root proliferation and low water absorption (Nweke and Nsoanya, 2013), all of which lead to depressed yields. More importantly, the greatest debilitating effect of soil acidity on groundnut yield is poor pod filling and prolonged maturity occasioned by abysmal $\mathrm{Ca}$ and $\mathrm{Mg}$ 
supplying power of the soil (Mulungu et al., 2013). Economical or break-even production of any crop requires ideal soil that lacks any physical or chemical impediments. Such soil needs good and best management practices, which could deliver desired and targeted productive yields. One of these measures is to develop technology appropriate for combating threat of soil acidity to profitable groundnut yield. The objectives of the research were to: (1) assess response of groundnut to different sources of lime; (2) determine the effect of different limes on soil physical and chemical properties. Despite litany of inundating literature on the effect of soil acidity on soil and groundnut productivity, it appears none has been conducted in the area of this study focus. Yet, it is envisaged as the main cause for unsatisfactory production in groundnut dominant agro ecology. This lack of information is suggestive of investigation.

\section{Material and Methods}

The study was carried out for two farming seasons (2018-2019) in Research Farm of Ebonyi State University, Abakaliki to elicit response of groundnut (Arachis hypogea L.) to lime application. Composite soil sample was collected from $0-20 \mathrm{~cm}$ depth at the site (0.05ha) before starting the experiment. The soil sample was air dried, grinded and sieved with $2 \mathrm{~mm}$ sieve, and then analyzed for physical and chemical properties (Table 1). The field was laid out in a randomized complete block design (RCBD). The plots measured $4 \times 4 \mathrm{~m}$ with $0.5 \mathrm{~m}$ spacing. The blocks were set apart by $1 \mathrm{~m}$ space. The treatments, namely: limestone $\left(\mathrm{CaCo}_{3}\right)$ and calcium oxide $(\mathrm{CaO})$ and wood ash at a rate of $0.2 \mathrm{tha}^{-1}$ each equivalent to 0.32 $\mathrm{kg} \mathrm{plot}^{-1}$ and control i.e. no application of lime were applied and incorporated according to treatments plan 14 days before planting groundnut seeds at $50 \times 20 \mathrm{~cm}$ distance for optimal yield. Two weeks after germination, seedlings were thinned down to one plant per hole to give a density of 100,000 population for a hectare. Missing stands were replaced through replanting. The field was kept relatively weed free by hand weeding at biweekly interval. The core and auger soil samples were collected from every plot at 0-20 cm depth at harvest for evaluation of physical and chemical properties. Samples collected with auger were sieved in a $2 \mathrm{~mm}$ sieve after grounding to determine chemical properties. Germination count was taken 5DAP to assess response to treatment after planting. A total of 30 plants representing $48 \%$ of plant density for a plot were tagged and used for agronomic determinations in order to elicit response of the crop to lime amendment. Plant height was determined at 12 weeks after planting (WAP) with meter rule from base of crop to tip of longest leaf. When the leaves turned brown with lower ones dried at 120 DAP, plants were carefully uprooted and nuts detached. Nuts were manually removed from shells and seeds dried at constant weight; approximately $\pm 14 \%$ moisture content for evaluation of grain yield. Samnut 10 variety of groundnut was used because of its high resistance to drought, diseases or pest infestation and has the advantage of relatively high yield with minimum management.

Table-1: Initial soil data

\begin{tabular}{|c|c|}
\hline Soil parameter & Value \\
\hline Sand $\mathrm{gkg}^{-1}$ & 650 \\
\hline Silt $\mathrm{gkg}^{-1}$ & 200 \\
\hline Clay gkg ${ }^{-1}$ & 150 \\
\hline Texture & Sandy loam \\
\hline $\mathrm{pH} \mathrm{Kcl}$ & 5.00 \\
\hline Available $\mathrm{P}$ mg Kg${ }^{-1}$ & 15.20 \\
\hline $\mathrm{N} \mathrm{gkg}^{-1}$ & 0.50 \\
\hline Organic $\mathrm{C} \mathrm{gkg}^{-1}$ & 1.10 \\
\hline $\mathrm{Ca} \mathrm{cmolkg}^{-1}$ & 2.50 \\
\hline $\mathrm{Mg} \mathrm{cmolkg}^{-1}$ & 1.70 \\
\hline $\mathrm{K} \mathrm{cmolkg}^{-1}$ & 0.20 \\
\hline $\mathrm{Na} \mathrm{cmolkg}^{-1}$ & 0.20 \\
\hline $\mathrm{CEC} \mathrm{cmolkg}^{-1}$ & 67.00 \\
\hline $\mathrm{BS} \%$ & 76.00 \\
\hline EA cmolkg $^{-1}$ & 1.40 \\
\hline $\mathrm{AL}^{3+\text { saturation } \%}$ & 3.50 \\
\hline Bulk density $\mathrm{gcm}^{-3}$ & 1.84 \\
\hline Total porosity $\%$ & 30.00 \\
\hline Hydraulic conductivity $\mathrm{cmhr}^{-1}$ & 0.29 \\
\hline Mean weight diameter mm & 11.86 \\
\hline
\end{tabular}

Particle size distribution, bulk density, total porosity and hydraulic conductivity as well as mean weight diameter (MWD) were determined as described by Obi (2000). Soil pH was evaluated using glass electrode $\mathrm{pH}$ meter by immersing it in a solution in the ratio of 1:2.5 of KCL and distilled water using $\mathrm{pH}$ meter, organic carbon by modified method of Nelson and Sommer (1982). Nitrogen was determined using micro kjeldahl method (Bremner and Mulvaney, 1982), available phosphorus by Bray 2 method (Bray and Kurtz, 1945), exchangeable $\mathrm{Ca}, \mathrm{Mg}, \mathrm{K}$ and $\mathrm{Na}$ 
through $\mathrm{NH}_{4} \mathrm{OAC}$ solution and values of $\mathrm{Ca}$ and $\mathrm{Mg}$ read off with atomic absorption spectrophotometer (AAS). While $\mathrm{K}$ and $\mathrm{Na}$ were determined with flame photometer (Mba, 2004), cation exchange capacity obtained using $\mathrm{NH}_{4}$ OAC displacement method (Mclean, 1982), base saturation by calculation and exchangeable acidity obtained through titration method (Juo, 1979). Data generated from laboratory and field were processed for statistical analysis using SAS (1985) and significant means separated with Fishers Least Significant Difference.

\section{Results and Discussion}

\section{Response of soil physical properties to lime application}

\section{Soil texture}

The texture of soil governs its nutrient supplying capacity, water regime, aeration, transportation pathway, root penetration, and indicative of general management approaches for higher productivity and sustainability. The texture of soil is a function of dominance of any of the three textures, namely: sand, silt and clay. If it is sandy, the soil will not support good crop growth and yield. Moderation of physical and chemical processes that enhance fertility will be difficult. Although, there were variations in realignment of particle sizes after treatment, sand fraction was still predominantly higher than silt and clay fractions as observed in the initial data. The variation did not affect the texture of the soil. This is supported by non effect of lime application on soil texture and separates (Hmielowski, 2017). The texture consistently remained sandy loam. Sandy loam is a medium light texture (Obi, 2000), and potentially well balanced for sustained fertility of soil. The marginal improvements due to realignment of particle sizes after liming indicate that prolonged application could lead to change in texture. Temporary management practices such as one- or two-years treatment of soil do not impact on soil texture (Obi, 2000). Change in texture will skew the behaviour of soil in terms of its fertility status and position it for increased productivity. The texture recorded in this study could be attributed to sand stone parent material that formed the soil (FDALR, 1985), against response effect to treatment.
Bulk density (BD), total porosity (TP) and hydraulic conductivity (HC)

Bulk density is a soil property which is used to assess improvement in amendment or otherwise. Decrease in soil density suggests good response to treatment. The parameter controls nutrient pathways, porosity, structure and water transmissivity, retention, aeration, seed germination as well as proper root ramification. Therefore, soil density has to be low in order to elicit good response from crop after amendment. Compared to initial and control data, bulk densities of lime treated plots were significantly $(\mathrm{p}<0.05)$ moved from critical and limiting to none limiting values for the periods. Lowest bulk densities (1.62 and $1.65 \mathrm{gcm}^{-3}$ ), were recorded for plots amended with wood ash for two seasons as well as plot amended with $\mathrm{CaCo}_{3}$ in the second season, which significantly accounted for higher 13\% respective reduction in bulk densities compared to control for the periods. Previous studies, Mbah et al. (2010); Okonkwo et al. (2008) reported significant reductions in bulk densities of plots amended with wood ash and burnt rice husk ash used as sources of lime. This improvement in bulk density is also attributed to increments in total porosities and MWD (Table 2) after application of lime sources. It further suggests efficacy of wood ash source of lime over chemical limes probably because of combined effects of presence of $\mathrm{Ca}, \mathrm{Mg}$ and $\mathrm{Na}$ in the lime. Bulk densities did not show significant differences among the treatments except in second season. This implies that limes have residual effect and careful application can further reduce density of soil except $\mathrm{CaO}$ for the benefit of a crop. Total porosities have inverse relationships with $\mathrm{BD}$ in all the treatments for the seasons.

Maximum significant total porosities were obtained (39.11 and 37.59\%) for wood ash treatment in first season and $\mathrm{CaCo}_{3}$ in second season. These represent 21 and $93 \%$ significant increments in total porosities over the control for the seasons. The plots amended with wood ash and $\mathrm{CaCo}_{3}$ significantly differed in TP from those treated with $\mathrm{CaO}$ for two periods. The rise in total porosity after lime application implies good response of soil to the amendment. Furthermore, this improvement could be linked to improved bulk densities and MWD as shown in Table 2. Hydraulic conductivity generally increased after lime amendment for the seasons. Highest significant $(\mathrm{P}<0.05)$ soil water transmission $\left(0.46\right.$ and $\left.0.45 \mathrm{~cm} \mathrm{hr}^{-1}\right)$ were respectively noted in plots amended with wood ash lime for first and second season, accounting for 35 and $61 \%$ 
increments in $\mathrm{HC}$ when compared to control. Improved $\mathrm{HC}$ is a good response, elicited after lime application and is a function of desirable bulk density and porosity due to lime treatment (Table 2). There were significant differences in $\mathrm{HC}$ among the lime sources, indicating their different potentials to transmit water in the soil. Effective water transmission is desirable as it will enhance proper aeration, mineralization and generally good rhizospheric condition for a benefitting crop.

\section{Mean weight diameter (MWD)}

MWD is used as index for assessing relative soil dispersability, resilience, and vulnerability or otherwise to disruptive forces. It is important for assessing stability of soil during tillage, trafficability and for sustained fertility. If the weighted mean is high, it suggests a good stable soil which would be able to resist collapsing forces, retain and provide nutrients as well as adequate moisture for high productivity. The data presented for initial and control data showed non-significant marginal variations when compared to MWD obtained after treatment for the periods under consideration. Maximum values of MWD (14.40 and 14.20mm) were recorded for plots that received $\mathrm{CaO}$ application for the periods relative to control accounting for 11 and $14 \%$ increments. There was marginal decline in MWD during the season of non-amendment. This finding tends to support the report of Erkki and Hedlund (2016) that quicklime $(\mathrm{CaO})$ mimicked biological soil processes through rapid formation and enhancement of aggregate structure. The marginal improvement elicited irrespective of lime sources compared to control agree with Cahn et al. (2017) submission that lime amendment improved soil structure. Improvement of soil MWD by lime can further be deduced to have come from catonic bridges (Obi, 2000), provided by the limes. Deterioration in MWD in second season implies low residual effect of limes on soil aggregation (Table 2).

\section{Response of soil chemical properties to lime application \\ Soil pH}

This important property is useful in understanding and evaluation of chemical processes going on in the soil. It controls both chemical and biological activities as well as growth, development, and yield of crops. At a pH range between strongly to and extremely acidic condition, the productivity of soil will be threatened as precipitation of nutrients becomes hindered, biological processes stifled and crop growth, development, and yield impaired.

Table-2: Response of soil physical properties to lime application

\begin{tabular}{|c|c|c|c|c|c|c|c|}
\hline Treatment & $\longleftarrow$ & gkg $^{-1}$ & $\longrightarrow$ & & & & 2018 \\
\hline Sand & Silt & Clay & Texture & $\mathrm{BD}\left(\mathrm{gcm}^{-3}\right)$ & TP(\%) & Hc $\left(\mathrm{cm} \mathrm{hr}^{-1}\right)$ & MWD(mm) \\
\hline Control & 680 & 140 & 180 & Sandy loam & 1.83 & 31.00 & 0.30 \\
\hline 12.00 & & & & & & & \\
\hline $\mathrm{CaCo}_{3}$ & 610 & 170 & 220 & Sandy loam & 1.67 & 35.01 & 0.30 \\
\hline 12.31 & & & & & & & \\
\hline $\mathrm{CaO}$ & 620 & 150 & 230 & Sandy loam & 1.68 & 35.10 & 0.31 \\
\hline 14.40 & & & & & & & \\
\hline Wood ash & 560 & 180 & 260 & Sandy loam & 1.62 & 39.11 & 0.46 \\
\hline 3.22 & & & \multicolumn{2}{|c|}{ FLSD $(\mathrm{P}<0.05)$} & & & \\
\hline 0.02 & 2.00 & 0.10 & & $\mathrm{NS}$ & & & \\
\hline & & & & & & & 2019 \\
\hline Control & 690 & 160 & 150 & Sandy loam & 1.86 & 28.29 & 0.28 \\
\hline 11.80 & & & & & & & \\
\hline $\mathrm{CaCo}_{3}$ & 620 & 180 & 200 & Sandy loam & 1.65 & 37.59 & 0.45 \\
\hline 12.26 & & & & & & & \\
\hline $\mathrm{CaO}$ & 640 & 160 & 210 & Sandy loam & 1.72 & 34.20 & 0.21 \\
\hline 14.20 & & & & & & & \\
\hline Wood ash & 600 & 180 & 220 & Sandy loam & 1.65 & 37.15 & 0.30 \\
\hline 13.20 & & & & & & & \\
\hline FLSD $(\mathrm{P}<0.05)$ & & & & & 0.20 & 2.00 & 0.12 \\
\hline
\end{tabular}

NS - Not Significant

BD- Bulk density, TP- Total porosity, MWD- Mean weight diameter, HC- Hydraulic conductivity 
Initial and control (Tables 1 and Table 2) data range from very strongly to strongly acidic condition (Landon, 1999), compared to values after lime application, which significantly $(\mathrm{p}<0.05)$ appreciated in the first season irrespective of type of lime except in the control. Calcium carbonate and wood ash limes gave highest $\mathrm{pH}$ levels (6.49 and 5.80) for two seasons, which represent 18 and $14 \%$ increments compared to control for the same periods. Unlike in the first season where $\mathrm{CaCo}_{3}$ (6.49) and wood ash (5.80) limes significantly differed in $\mathrm{pH}$, lime sources did not differ in the second season. There were general significant reductions in $\mathrm{pH}$ after first season compared to period of non amendment. The maximum significant increase in $\mathrm{pH}$ recorded from plots that received $\mathrm{CaCo}_{3}$ suggests higher solubility and rapid degradation effect of the lime on soil (Nduwumuremyi, 2010), more than other lime sources. The superiority shown by $\mathrm{CaCo}_{3}$ and wood ash limes over $\mathrm{CaO}$ could be linked to higher solubility of limes (Snyder and Leep, 2007). From the finding, lime sources have different potentials for residual effect (Table 3) for which wood ash application has advantage of benefit to the immediate crop.

\section{Available phosphorous (P)}

Available P is a key element in crop nutrition. It is very essential for bio-chemical processes and a component of nucleic acid, nucleo-protein, enhance fruit maturation and ripening. The result of initial and control data (Tables 1 and 3) show low $\mathrm{P}$ before application of lime sources. Superior values $(28.00$ and $\left.26.00 \mathrm{mg} \mathrm{kg}^{-1}\right)$ of significant $\mathrm{P}(\mathrm{P}<0.05)$ were obtained from plots amended with $\mathrm{CaCo}_{3}$ in the first season and wood ash for second season. These represent $31 \%$ each significant increments in $\mathrm{P}$ for those lime sources in contrast to control for the seasons. Lime sources were not significantly different for the periods except that $\mathrm{P}$ generally decreased in the second season. The increase in $\mathrm{P}$ elicited after lime application is attributed to conditioning effect on one hand and higher presence of $\mathrm{N}$ and OC (Table 3) as well as soil $\mathrm{pH}$. More $\mathrm{OC}$ and $\mathrm{N}$ in plots that received different sources of lime facilitated micro biological decomposition (Bergmann et al., 2003) of available organic materials that increased $\mathrm{P}$ in the soil. Furthermore, more available increased cations (Table 4) reduced $\mathrm{Al}$ or $\mathrm{Mn}$ solubilities to favour precipitation of available $\mathrm{P}$. Lower $\mathrm{P}$ in subsequent season could be due to low residual effect and crop utilization of nutrients. More importantly, $\mathrm{P}$ was moved from low to medium values after liming in soil (FMARD, 2002).

\section{Nitrogen (N) and organic carbon (OC)}

Nitrogen and OC are parameters that indicate level of soil fertility status. When the $\mathrm{OC}$ is high, $\mathrm{N}$ availability in soil is boosted. The two are synergistic and their presence can give satisfactory crop growth and yield. The data for $\mathrm{N}$ and $\mathrm{OC}$ as in Tables 1 and 3 show initial and control values which range from low to critical and inadequate for crop growth (FMARD, 2002), and sustained yield under tropical regions for the periods with respect to their counterparts after amendment. The $\mathrm{N}$ values $(0.77$ and $0.67 \mathrm{gkg}^{-1}$ ) were highest for plots amended with $\mathrm{CaCo}_{3}$ and $\mathrm{CaO}$ for the periods and these gave 13 and $7 \%$ significantly higher $\mathrm{N}$ when compared to control for the intervening periods. Except for $\mathrm{CaCo}_{3}$ and $\mathrm{CaO}$ limes that significantly differed from wood ash in first season, lime sources were statistically the same in the season of non amendment. Nitrogen declined during subsequent season. The OC for preplanting and post-harvest control data (Tables 1and 3) were low. However, after amendment, it significantly $(\mathrm{P}<0.05)$ appreciated in all plots that received different sources of lime with highest (2.90 and $1.40 \mathrm{gkg}^{-1}$ ) for $\mathrm{CaCO}_{3}$ and $\mathrm{CaO}$ for the two seasons. These account for respective 59 and 5\% increments in OC when compared to control for the same periods.

Table-3: Response of soil $\mathrm{pH}, \mathrm{P}, \mathrm{N}$, and $\mathrm{OC}$ to lime application

\begin{tabular}{|c|c|c|c|c|}
\hline & & & $\mathbf{2 0 1 8}$ & \\
\hline Treatment & $\mathbf{p H}(\mathbf{K C L})$ & $\mathbf{P}\left(\mathbf{m g k g}^{-1}\right)$ & $\mathbf{N}(\boldsymbol{\%})$ & $\mathbf{O C ~ g k g ~}^{-1}$ \\
\hline $\mathrm{Control}$ & 5.30 & 19.20 & 0.67 & 1.19 \\
\hline $\mathrm{CaCo}_{3}$ & 6.49 & 28.00 & 0.77 & 2.90 \\
\hline $\mathrm{CaO}$ & 6.02 & 26.00 & 0.77 & 2.50 \\
\hline Wood ash & 6.45 & 27.00 & 0.68 & 2.80 \\
\hline $\begin{array}{c}\text { FLSD } \\
(\mathrm{P}<0.05)\end{array}$ & 0.05 & 2.20 & 0.03 & 0.50 \\
\hline & & & $\mathbf{2 0 1 9}$ & \\
\hline Control & 5.00 & 18.00 & 0.60 & 1.14 \\
\hline $\mathrm{CaCo}_{3}$ & 5.60 & 25.63 & 0.67 & 1.17 \\
\hline $\mathrm{CaO}$ & 5.00 & 24.90 & 0.67 & 1.20 \\
\hline Wood ash & 5.80 & 26.00 & 0.66 & 1.19 \\
\hline $\begin{array}{c}\text { FLSD } \\
(\mathrm{P}<0.05)\end{array}$ & 0.03 & 2.50 & 0.03 & 0.20 \\
\hline
\end{tabular}

$\mathrm{P}$ - available phosphorous, $\mathrm{N}$ - Nitrogen, OC- organic carbo 
Although, OC values were generally low in second season when compared to the first season, there were no significant differences among the different sources of lime for the periods. Increased $\mathrm{N}$ in the limed plots could be as a result of improved decomposition of organic materials as well as $\mathrm{N}$ transformation pathways owing to high $\mathrm{pH}$ (Table 3). Similarly, increased OC in the soil (Table 3) could have boosted $\mathrm{N}$ in the soil following treatment.

Superiority exhibited by $\mathrm{CaCo}_{3}$ and $\mathrm{CaO}$ limes suggests their efficacy probably, because of their relative quicker solubility and action. The reduction observed during second cropping season implies poor residual effect of the limes on $\mathrm{N}$ availability. Maximum significant $\mathrm{OC}$ recorded for plots that received lime could be due to slightly acidic condition of soil which created favorable condition for proliferation of $\mathrm{P}$ and $\mathrm{N}$ (Table 3) that precipitated high $\mathrm{OC}$ obtained in $\mathrm{CaO}$ lime when compared to other lime sources in the second season. This could be further attributed to residual effect and soil dynamics, suggesting probably, more solubility with progress in time which could be beneficial to subsequent cropping. The limes were able to raise $\mathrm{OC}$ and $\mathrm{N}$ from low to high levels after lime amendment. Findings suggest that lack of continuous application of lime is more critical on availability of OC than N (Table 3). This could largely be linked to high degradation of OC and $\mathrm{N}$ in soil and due to crop utilization.

\section{$-+$}

\section{Exchangeable $\mathrm{Ca}, \mathrm{Mg}, \mathrm{K}, \mathrm{Na}$, and CEC}

The exchangeable cations of $\mathrm{Ca}, \mathrm{Mg}, \mathrm{K}, \mathrm{Na}$ and $\mathrm{CEC}$ control degree of exchange complex as well as buffer capacity of soil. These soil properties directly or indirectly determine fertility status of soils. Tables 1 and 3 for initial and control data show low $\mathrm{Ca}, \mathrm{Mg}$, $\mathrm{K}, \mathrm{Na}$ and $\mathrm{CEC}$ in the soil compared to their corresponding values after lime amendment for the period of the study. Wood ash lime gave highest values $\left(3.80\right.$ and $\left.3.70 \mathrm{cmolkg}^{-1}\right)$ of $\mathrm{Ca}$ for the intervening periods resulting to 32 and $30 \%$ higher significant improvements in $\mathrm{Ca}$ when compared to the control. Calcium content of the soil decreased in the second season. Conversely, $\mathrm{CaCo}_{3}$ and wood ash recorded highest $\mathrm{Mg}\left(1.80 \mathrm{cmolkg}^{-1}\right)$ for first season, and wood ash $\left(1.74 \mathrm{cmolkg}^{-1}\right)$ for the second season, accounting for 172 and $28 \%$ significant increments in $\mathrm{Mg}$ contents for the periods. Similarly, Mg contents were lower in the second season than their corresponding values in the first cropping season. For the two seasons, $\mathrm{K}$ did not show any significant response to lime application except marginal improvements for plots that received different sources of lime when compared to control. The plot treated with Wood ash recorded highest values $(0.13$ and $0.13 \mathrm{cmolkg}^{-1}$ ) of $\mathrm{Na}$, accounting for 15 and $23 \%$ higher significant increments when compared to the control for the intervening periods. Similarly, the highest CEC (8.94 and $1.02 \mathrm{cmolkg}^{-}{ }^{1}$ ) contents were obtained for plot amended with $\mathrm{CaCo}_{3}$ for the two seasons. These represent 22 and $20 \%$ higher significant responses of $\mathrm{CEC}$ to $\mathrm{CaCo}_{3}$ lime application for the seasons. Cation exchange capacity was generally lower in the soil after first season. The relative increments in $\mathrm{Ca}, \mathrm{Mg}, \mathrm{K}, \mathrm{Na}$ and $\mathrm{CEC}$ after application of different sources of lime in the soil could be attributed to their presence in the limes, which were released to the soil (Table 1). The presence of $\mathrm{Ca}$ already in the soil also boosted availability of $\mathrm{Ca}, \mathrm{Mg}, \mathrm{K}$ and $\mathrm{Na}$ and further enhanced CEC in the plots that received lime amendment (Table 4). In addition, desirable $\mathrm{pH}$ and high $\mathrm{OC}$ in plots treated with limes created ideal condition for increase of $\mathrm{Ca}, \mathrm{Mg}, \mathrm{K}, \mathrm{Na}$ and CEC (Table 3) in the soil. The report of Nduwumurenyi (2010) that CEC was significantly high in lime treated plots tends to support this finding. The author noted that CEC was at maximum level for a plot that received $\mathrm{CaCO}_{3}$ lime. The differences observed in different sources of lime in their improvement of $\mathrm{Ca}$, $\mathrm{Mg}, \mathrm{K}, \mathrm{Na}$ and $\mathrm{CEC}$ indicate their relative efficiencies in creating suitable soil condition for higher productivity (Table 4). The general reductions in these parameters in the second season imply that these lime sources have low residual effect, exacerbated by diminution from crop nutrition and continuous cultivation.

\section{Base saturation (BS)}

This parameter is used to determine the extent of saturation of soil medium with bases. If the soil base saturation is high it then implies that $\mathrm{pH}$, cation exchange and buffer capacity would operate at optimal level. Low base saturation suggests poor and infertile soil that would be low in productivity. Both initial and control data (Tables 1 and 4) indicate moderate BS, which significantly $(\mathrm{P}<0.05)$ improved plots treated with different sources of lime giving maximum ( 87.28 and $86.57 \%$ ) values for wood ash amended plot for the periods. These account for $29 \%$ each significant response of BS to wood ash 
application for the seasons. Furthermore, wood ash lime differed from $\mathrm{CaO}$ lime significantly in both seasons. Even though, BS was moved by lime application from medium to high status (Landon, 1999) for both seasons, the values generally declined during subsequent cropping season. Significant high BS for plots amended with different sources of lime could be due to higher exchangeable $\mathrm{Ca}, \mathrm{Mg}, \mathrm{K}$ and $\mathrm{Na}$ made available by liming the soil (Tables 2and 4). Previous studies, Okonkwo et al. (2008); Hmielowsk (2017); Hinterthur (2017) had reported significant increments in BS after lime application. The synergistic action of CEC, OC, $\mathrm{N}$ and $\mathrm{pH}$ also contributed to increased BS in plots amended with lime (Tables 2 and 3). Decreased BS in subsequent season could be attributed to the general trend of influx of nutrients, crop nutrition and soil dynamics in the second season (Tables 2, 3 and 4).

Table-4: Response of exchangeable properties and BS to lime Application

\begin{tabular}{|c|c|c|c|c|c|c|}
\hline & $\bar{L}$ & cmolkg $^{-1}$ & 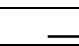 & & $\longrightarrow$ & 2018 \\
\hline Treatment & $\mathrm{Ca}$ & Mg & $\mathbf{K}$ & $\mathrm{Na}$ & CEC & $\begin{array}{l}\text { BS } \\
(\%)\end{array}$ \\
\hline Control & 2.60 & 1.30 & 0.14 & 0.11 & 6.95 & 62.30 \\
\hline $\mathrm{CaCo}_{3}$ & 3.20 & 1.80 & 0.15 & 0.11 & 7.88 & 84.15 \\
\hline $\mathrm{CaO}$ & 3.40 & 1.50 & 0.15 & 0.11 & 7.88 & 84.15 \\
\hline Wood ash & 3.80 & 0.15 & 0.15 & 0.13 & 7.81 & 87.28 \\
\hline $\begin{array}{c}\text { FLSD } \\
(\mathrm{P}<0.05)\end{array}$ & 1.80 & 0.20 & NS & 0.01 & 2.00 & 2.50 \\
\hline & & & & & & 2019 \\
\hline Control & 2.58 & 1.26 & 0.13 & 0.10 & 0.82 & 61.54 \\
\hline $\mathrm{CaCo}_{3}$ & 3.00 & 1.70 & 0.14 & 0.12 & 1.02 & 85.26 \\
\hline $\mathrm{CaO}$ & 3.10 & 1.60 & 0.14 & 0.11 & 1.00 & 84.35 \\
\hline Wood ash & 3.70 & 1.74 & 0.14 & 0.13 & 0.84 & 86.57 \\
\hline $\begin{array}{c}\text { FLSD } \\
(\mathrm{P}<0.05)\end{array}$ & 1.70 & 1.10 & NS & 0.01 & 0.20 & 2.50 \\
\hline
\end{tabular}

CEC- Cation exchange capacity, BS- base saturation

\section{Response of groundnut yield parameters to lime application}

The major interest which is central to any farmer is the yield data of a crop. A desirable soil condition is a prerequisite for good germination, anchorage, growth and yield of crop as it is the very essence for amendment. With loose, well aerated and enhanced moisture regime as well as relative fertility status of soil, the test crop was therefore positioned for faster response in germination, establishment and economical yield. Yield parameters for control were significantly $(\mathrm{P}<0.05)$ lower compared to yield responses for the plots treated with different sources of lime for the prevailing periods. Germination was faster in plots amended with $\mathrm{CaCo}_{3}$ (100 and 99\%) and wood ash (100 and 98\%) at < 5DAP, maximum sprouting, accounting for $10-11 \%$ and $11-10 \%$ significantly higher groundnut germination for the amendments with respect to control for the periods was attained. There was better response of groundnut in terms of sprouting under lime application in the first season than in the subsequent season (Table 5). The plot that received $\mathrm{CaCo}_{3}$ lime gave highest plant heights $\left(37.02\right.$ and $\left.30.35 \mathrm{~cm} \mathrm{plot}^{-1}\right)$ for the periods corresponding to 10 and $7 \%$ respective significant higher groundnut heights when compared to the control for the periods. In addition, groundnut height for $\mathrm{CaCo}_{3}$ and woodash amended plots were significantly different from that of $\mathrm{CaO}$ lime in the first season (Table 5). The height of the crop decreased with continuous cultivation. Maximum pod yields $\left(2.70\right.$ and 2.42 tha $\left.^{-1}\right)$ were recorded for $\mathrm{CaCo}_{3}$ lime treated plot when compared to the control for the two seasons. These resulted to 57 and $55 \%$ increments in pod yields over control for the periods under study. Pod yield irrespective of source of lime, decreased with wood ash giving lowest (1.59 and 2.10 tha $^{-1}$ ) values, accounting for 26 and $48 \%$ reductions when compared to control for the two seasons. The seed yields followed the trend of pod yields with highest values (1.46 and 1.35 tha $^{-1}$ ) obtained for plot treated with $\mathrm{CaCo}_{3}$ lime which account for 30 and $26 \%$ significantly higher seed yields of groundnut for the treatment compared to control for the intervening periods. Additionally, pod yield of groundnut for $\mathrm{CaCo}_{3}$ was significantly different from that of $\mathrm{CaO}$ in the second season. Except in the first season where seed yield of groundnut from $\mathrm{CaCo}_{3}$ amended plot was significantly higher than yields recorded for $\mathrm{CaO}$ and wood ash, the yields from different sources of lime application generally remained statistically the same and lower in the second season. The significant positive responses elicited from yield parameters of groundnut could be attributed to desirable soil conditions created by application of lime (Tables 2, 3 and 4) compared to control. Similar reports of quicker and earlier germination of groundnut seed in plots treated with limes were noted (Ajeigbe et al., 2016) in their studies. Significant increase in pod and seed yields for lime amended plots agrees with the findings of Hosseienzabe et al. (2013) and Ajeigbe et al. (2016). The fastest germination rate and height expressed in plots treated with limes (Tables 3 and 4) largely contributed to significant yield under the 
treatments. Poor and uneconomical yields manifested during subsequent season imply lower nutrients utilization, less desirable physical and chemical properties (Tables 2, 3 and 4) as well as influence of continuous cultivation. Relatively better yield responses obtained in plot treated with $\mathrm{CaCo}_{3}$ compared to other lime sources suggests its superior soil conditioning quality (Tables $2,3,4$ and 5) to improve and sustain groundnut yield. There were total production loses of between 89 and $76 \%$ annually for the two seasons due to none application of lime sources. This makes it counterproductive to embark on groundnut production on acid soil condition without lime application especially for the agro study area.

Table-5: Response of groundnut yield parameters to lime application

\begin{tabular}{|c|c|c|c|c|}
\hline & & 20184 & t ha ${ }^{-1}$ & \\
\hline Treatment & $\begin{array}{c}\text { Germination } \\
\text { count }(\%)\end{array}$ & $\begin{array}{l}\text { Height } \\
\left(\mathrm{cm}^{-1}\right. \\
\left.\text { plot }^{-1}\right)\end{array}$ & Pod & Seed \\
\hline Control & 90 & 33.35 & 1.17 & 1.02 \\
\hline $\mathrm{CaCO}_{3}$ & 100 & 37.02 & 2.70 & 1.46 \\
\hline $\mathrm{CaO}$ & 98 & 34.23 & 2.68 & 1.26 \\
\hline Wood ash & 100 & 36.87 & 2.59 & 1.24 \\
\hline \multirow[t]{2}{*}{$\begin{array}{c}\text { FLSD } \\
(\mathrm{P}<0.05)\end{array}$} & NS & 2.50 & 0.35 & 0.20 \\
\hline & & 2019 & & \\
\hline Control & 88 & 28.20 & 1.09 & 1.00 \\
\hline $\mathrm{CaCo}_{3}$ & 99 & 30.35 & 2.42 & 1.35 \\
\hline $\mathrm{CaO}$ & 95 & 29.34 & 2.10 & 1.20 \\
\hline Wood ash & 98 & 29.49 & 2.27 & 1.21 \\
\hline $\begin{array}{c}\text { FLSD } \\
(\mathrm{p}<0.05)\end{array}$ & NS & 1.80 & 0.25 & 0.23 \\
\hline
\end{tabular}

\section{Conclusion}

A good management approach to elicit desired crop response for higher productivity is to amend the soil in order to keep it under desirable and optimal condition. Low $\mathrm{pH}$ is destabilizing to soil fertility and productivity. The disadvantages far outweigh any seemingly advantage. For instance, application of any lime source on soil indicates strong ameliorative capacity to soil condition because it improves both physical and chemical properties. Groundnut yield parameters responded significantly with superior data compared to non amended plot. The study concludes that one season of lime application is not enough for sustainable soil improvement for profitable groundnut production. The contribution to knowledge applicable to groundnut farmers or other critical stakeholders from this study is that they can improve soil degradation due to low $\mathrm{pH}$ (acidity) and increase productivity by applying either $\mathrm{CaCo}_{3}$ or woodash at $0.2 \mathrm{t} \mathrm{ha}^{-1}$ or $0.32 \mathrm{~g} \mathrm{plot}^{+3}$ or $\mathrm{CaO}$ at the same rate. Due to cost of procurement of $\mathrm{CaCo}_{3}$ and $\mathrm{CaO}$, wood ash that is cheap and readily available is recommended for use by poor resource or peasant farmers for improving soil degradation due to low $\mathrm{pH}$ and increasing productivity.

\section{Acknowledgement}

We thank Andrew Craig, Eleftherios Avramidis and Hola Adrakey for helpful discussions. We also thank two anonymous reviewers for their helpful and constructive comments.

Disclaimer: None.

Conflict of Interest: None. Source of Funding: None.

\section{References}

Adeli A, Read J, Brooks JP, Miles D, Feng G and Jenkins JN, 2017. Effect of gypsum and broiler litter and industrial by-products application on nutrient availability and microbial losses on surface runoff. J. of Env. Qual. 46: 43-48.

Ajeigbe HA, Abdoulaye T and Chikoye D, 2016. Cowpea and groundnut seed production practices for improved yields in Nigeria. In: Proceedings for the training workshop on production of legume and cereal seeds, $24^{\text {th }}$ Jan-10 Feb. 2016, IITA, Kano, Nigeria p.108.

Angin I and Yaganoglu AV, 2011. Effects of sewage sledge application on physical and chemical properties of a soil affected by wind. J. of Agric. Sc. Tech. 13: 757- 768.

Anikwe MAN, Mbah CN, Ezeaku PI and Onyia VN, 2005. Ecophysiology and Cultivation 
Practices of Arable Crops. New Generation Bookshop 51, Nnamdi Azikiwe Stadium Shopping Mall, Ogui Road, Enugu, Nigeria, pp. 1-350.

Bergmann R, George H, Alessandro F and Fabrizo N, 2003. Resolving vertical tectonics in the San Francisco Bay Area from permanent Scatter insar and GHS analysis. Geology 7:221-224.

Bray RH and Kurtz LT, 1945. Determination of total and available forms of phosphorous. J. of Soil Sc. 56: 39- 45.

Bremner JM and Mulvaney CS, 1982. Total nitrogen. CA Black methods of soil analysis. Amer. Soc. of Agron. 2 (9): 1149- 11778.

Cahn MR, Smith R, Murphy L and Hartz, 2017. Calculating Fertilizer credits. In Field trials show the fertilizer value of nitrogen in irrigation water. California Agr. 71 (2): 62- 67.

Donovan CM, Damaseke J, Govereh D and Simumbad, 2002. Framework and initial Analysis of fertilizer profit ability in maize and cotton in Zambia, Lusaka, Zambia: Food Security Res. Proj. pp. 10- 15.

Erkki P and Hedlund K, 2016. Effects of structural liming on soil biology. Swedish Agriculture, pp. 11-85.

Federal Department of Agricultural Land Resources (FDALR), 1985. Reconnaissance Soil Survey of Anambra State, Nigeria. Soil Report FDALR, Kaduna, p. 3.

Federal Ministry of Agriculture and Rural Development (FMARD), 2002. Fertilizer use and management practice for crops in Nigeria. In EA aduayi, or chude BA Adebusayi, GO Olijiwola (eds). Federal fertilizer department, Abuja, pp. 1-88.

Hinterthur AH, 2017. Can ancient grains find their way in modern agriculture? Crop Sci. Soc. Am. 2: 4-9.

Hmielowski T, 2017. Timing and type of manure application + cover crops. In measuring nitrous oxide emissions from agriculture. News Bulletin. pp. $10-13$.

Hosseienzabe GA, Vishhekasi MN and Hosseinzadeh MH, 2013 Effects of potassium and calcium application TO yield, Yield components and qualitative characteristics of peanut (Arachis Hypogea L.) in Guilan province in Iran. World Appl. Sci. J. 16: $540-$
$546 ?$

Juo AR, 1979. Method for determination of soil exchange acidity. In all page, $\mathrm{RH}$ miller and DR Keneey (eds). Methods for soil analysis; part 1, Madison, Wisconsin, USA. pp. 78.

Landon JR, 1999. Booker tropical soil manual: A handbook for soil survey and Agricultural land Evaluation in the tropics and sub-tropics. New York, USA, John Wiley and sons. Inc. Third Avenue 474.

Lourduraji AC, 1999. Nutrient management in groundnut (Arachis hypogeal 1.) cultivation. Agric. Rev. 20 (1):14 - 20.

Mba CC, 2004. Selected methods for soil, plant and environment analysis .department of soil science. Hand book for department of soil science, university of Nigeria, Nsukka. p. 47.

Mbah CH, Nwite JN and Nweke IA, 2010. Response of maize (zea mays 1.) to different rates of wood ash application of an acid ultisol in southeastern Nigeria. Afr. J. Agric. Res. 5 (7): 580-583.

Mclean EO, 1982. Soil pH and lime requirement. In AL page, RH miller and Dr Keneey (eds). Methods of soil analysis. Monograph. 2(2): 198.

Mukhtar AA, Odion EC, Ahmed A, Babaji BA, Aminu Mukhtar M and Arunah UL, 2014. Comparative effects of organic manure sources and rates on performance of groundnut varieties. In: G Rahman and U Aksoy (eds) in proceedings of $4^{\text {th }}$ scientific Annual conference, ISOFAR, 13-15 October 2014, Istanbul, Turkey. pp. 843-850.

Mulungu K, Tembo G and Kabwe S, 2013. An economic analysis of precision Application of lime at reduced rates. J. Econ. and Sust. Dev. 4(17): 211-214.

National Programme for Agriculture and Food security (NPAFS), 2010. Federal Ministry of Agriculture and Rural Development. Report on Agricultural Production Survey. pp. 1-76.

Nelson DW and Sommer LE, 1982. Total carbon, organic carbon and organic matter .In AL page (eds). Methods of soil analysis: chemical and microbiological properties. Am. Soc. Agric. 2(2): 320-328.

Ntare BR, Diallo AT, Ndeunga AT and Waliyar F, 2008 .Groundnut seed production manual 
international crops Research Institute for the semi Arid Tropics, Andhra Pradesh, India. P.20.

Nweke A and Nsoanya N, 2013. Soil PH as on indicies for effective management of soils for crop production. Int. J. Tech. Sci. Res. 2(3): 2277-2288.

Obi ME, 2000. Soil physics. In A compendium of soil physics. Atlanto Publishes, Nsukka, Nigeria. pp. 40-48.

Ohiri A and Ano AO, 1988. Determination of exchangeable cations. Laboratory handbook of the National Root Crops Research Institute Umudike, Umuahia. pp. 1-15.

Okonkwo CL, Mbagwu JSC and Nwoke FN, 2008. Tillage effect on selected properties of an utitisol and adaptability of direct seed bed up land rice in Abakaliki Nigeria. Int. J.

Ranga GV, Raneshwar RV and Nigerian SN, 2010. Post-harvest insect pests of groundnut and the management. Info. Bull. 84: 324-502.

SAS Institute, 1985. User's guide, 1985 (eds). Statistical analysis systems institute, Inc .Cary NC.

Snyder CS and Leep RH, 2007. Effect of Potassium and Nitrogen Fertilizer on Switch grass productivity and Nutrient Removal Rates under two harvest systems on a low potassium soil. In: Bames RF, Nelson CJ, Moore KJ and Collins (eds). 2012. Forages: The Science of grassland Agriculture II: Springer, pp. 329-335.

Sobulo RA, 2000. Fertilizer use and soil testing in Nigeria. In: Agronomy in Nigeria. A Book on the theory and practice of agronomy as it has been in the last 33 years (from July 1967 to the present) in support of the activities of the department of Agronomy. University of Ibadan Press, pp. 195201.

\section{Contribution of Authors}

Nte NJ: Conceived the idea, designed research methodology, data analysis, literature review and manuscript write up Sunday IT: Helped in designing research methodology, data collection and data interpretation

Solomon AO: Helped in designing research methodology, data collection and data interpretation Onyeogoziri EC: Helped in designing research methodology, data collection and article write up Uguru NS: Helped in data analysis, interpretation and the discussion

Nwangele MB: Helped in data analysis, interpretation and the discussion Ebuka OJ: Helped in data collection and analysis 